Bangladesh J. Bot. 49(4): 1021-1027, 2020 (December)

\title{
INDIRECT ORGANOGENESIS AND SOMATIC EMBRYOGENESIS FOR REGENERATION OF RAUVOLFIA SERPENTINA L. FROM ROOT EXPLANTS
}

\author{
Tanjina Akhtar Banu, Salim Khan, Barna Goswami, \\ Sadia Afrin, Ahashan Habib and Shahina Akter* \\ Plant Tissue Culture Section, Biological Research Division, Bangladesh Council of \\ Scientific and Industrial Research, Dhanmondi, Dhaka-1205, Bangladesh
}

Keywords: Rauvolfia serpentina, Somatic embryogenesis, Indirect organogenesis

\begin{abstract}
Highest frequencies $(75 \%)$ of friable embryogenic nodular calli were recorded from the root explants in the presence of MS $+4.0 \mathrm{mg} / \mathrm{l} \mathrm{BAP}$ and $4.0 \mathrm{mg} / \mathrm{l} \mathrm{NAA}$. In combinations of BAP and NAA $45.4 \%$ callus produced direct plantlets formation and $36.3 \%$ only from aerial part of shoots. MS medium with $1.0 \mathrm{mg} / \mathrm{l}$ BAP and $0.5 \mathrm{mg} / \mathrm{l} \mathrm{Kn}$ produced compact callus where $13.3 \%$ produced direct plantlets formation and $45.7 \%$ produced only shoot formation. Well-developed globular somatic embryos were found to form when the callus were cultured more than 6 - 8 weeks on MS with $1.0 \mathrm{mg} / \mathrm{l} \mathrm{BAP}$ and $0.5 \mathrm{mg} / \mathrm{l} \mathrm{Kn}$. After acclimatization the well rooted plantlets were transferred to pot and grown successfully in soil.
\end{abstract}

\section{Introduction}

Medicinal plants are an important sources of compounds for the pharmaceutical industry. Increase in world population poses huge challenges to satisfy the demands for herbal medicine. Medicinal plant includes various types of plants used in herbalism (Ghat et al. 2019). There are many species of medicinal plants which are rare, endangered, or threatened with extinction, and their germplasm needs to be conserved, multiplied and improved. Rauvolfia serpentine L. an endangered medicinal shrub belonging to family Apocynaceae is native to Indian sub-continent and East Asian countries (Khan et al. 2018). Its local name is Sarpagandha in Bangladesh. Roots of Sarpagandha contains more than 50 various alkaloids (Verma and Verma 2010) which have medicinal value. The total alkaloidal content of the roots from different sources varies considerably, ranging from 1.7 to 3.0 per cent (Sharma and Gaikar 2012). The maximum alkaloid content detected in regenerated roots was 3.3\% (Panwar and Guru 2011). The alkaloids are concentrated mostly in the bark of the roots (Klushnichenko et al. 1995). The stem and leaf also contain alkaloids, but in very minute amount. Major alkaloids are ajmalinine, ajmalidine, ajmaline, reserpine, rescinnamine, serpentine, serpentinine, sarpagine, monoterpene, ajmaricidine, arne, raubasine, raucaffricine, canescineyo-himbine, and yohimbinine etc. (Panwar and Guru 2011).

There is also great demand for the alkaloids as well as the raw drug in the international market. The world requirement of dried 'Sarpagandha' roots is around 20,000 ton/year (Paturkar and Khobragade 2016) consumption of the raw drug is substantial in the indigenous drug market. This is possible only if the plant is brought under large-scale cultivation in agro-climatically suitable areas. The plant is usually propagated by seeds, irregular and very low percentage of germination of seeds is the main difficulty in the propagation of Rauvolfia. Moreover, the major threat of declination of this plant species from natural habitat is over exploitation and habitat loss (Ahmed et al. 2008). In vitro cell and tissue culture methodology is envisaged as a mean for

*Author for correspondence: <shupty2010@gmail.com>. 
germplasm conservation to ensure the survival of endangered plant species, rapid mass propagation for large scale re-vegetation, and for genetic manipulation studies. Secondary metabolites of $R$. serpentina have got potential application as therapeutics and during past few years considerable attention has been focused on the use of plant cell cultures as a source of secondary metabolites. If a small portion/section of tissue from a medicinally important plant is grown in vitro and produced callus culture, then secondary metabolites or drug can be directly extracted from the callus tissue without sacrificing the whole plant. So this alternative technique helps the conservation of medicinal plants in nature. There are a number of reports on in vitro regeneration of $R$. serpentina using leaf and nodal explants (Susila et al. 2013, Khan et al. 2018). But no report is available in Bangladesh using root explants. Various indole alkaloids and related constituents have been isolated from the roots of this plant which have significant biological activities (Itoh et al. 2005). Therefore, attempt was made to develop a regeneration system from the root explants of $R$. serpentina through indirect organogenesis along with somatic embryogenesis to obtain large number of plants as an alternative source of secondary metabolites in colossal quantity.

\section{Materials and Methods}

The root segment explants were collected from in vitro regenerated plantlets of Rauvolfia serpentina $\mathrm{L}$. which were cultured in Plant Tissue Culture Laboratory of BCSIR, Dhaka. For the induction of calli from 0.5 to $0.8 \mathrm{~cm}$ root segments were excised from in vitro regenerated plantlets cultured on MS (Murashige and Skoog 1962) media containing $30 \mathrm{~g} / \mathrm{l}$ sucrose and supplemented with BAP, NAA, IAA and Kn singly or in combinations. In vitro regenerated calli and embryogenic calli were sub-cultured regularly to fresh medium at an interval of 28 - 30 days for further multiplication. All in vitro grown cultures were maintained under illumination on a 16 hrs photoperiod at $25 \pm 2^{\circ} \mathrm{C}$. Fully regenerated plantlets from the callus were transplanted in soil and the regenerated shoots were excised and transferred to half strengths of MS with $0.2 \mathrm{mg} / \mathrm{l}$ IBA. The well rooted plantlets were then kept in room temperature for $2-3$ days and transferred to plastic pot containing garden soil and compost in a ratio of $2: 1$ and was moistened them adequately for proper hardening.

\section{Results and Discussion}

Root segment as explants was tested for callus induction on MS medium with different concentrations and combinations of plant growth regulators. The morphogenetic responses of the callus cultures of root segment of $R$. serpentina varied conferring to the treatment. Several growth regulators like BAP, Kn, NAA, IAA, 2,4-D, IBA were added to culture media individually and in combination to find out their effect on regeneration. Embryogenic, rhizogenic and nonembryogenic callus were obtained on MS medium with different hormonal concentrations. Combinations of MS with BAP + Kn and MS with BAP + NAA showed the sign of response towards callus formation as well as morphogenesis (Tables 1 and 2). $\mathrm{MS}+4.0 \mathrm{mg} / \mathrm{l} \mathrm{BAP}+4.0$ $\mathrm{mg} / \mathrm{l} \mathrm{NAA}$ was found to produce highest callus formation (Table 1). Media containing higher (4.0 $\mathrm{mg} / \mathrm{l}$ ) BAP and NAA stimulated various type of morphogenesis (Table 2). Pandey et al. (2010) reported good regeneration response from leaf segment explants of $R$. serpentina on MS medium containing $1.0 \mathrm{mg} / \mathrm{l} \mathrm{BA}+4.0 \mathrm{mg} / \mathrm{l} \mathrm{NAA}$. Callus was induced from root explants of $R$. serpentina using $2.0 \mathrm{mg} / \mathrm{l} \mathrm{BAP}$ and $0.8 \mathrm{mg} / \mathrm{l} \mathrm{NAA}$ and later induced to bud formation which further developed into shoots reported by Gomathi (2015). Goswami et al. (2018) also found good response using BAP and NAA in Brassica juncea. 
In the presence of BAP and NAA cream color or yellowish-white, friable and/or compact with nodular structures like embryogenic callus were induced within two weeks from the root segments (Fig. 1a). On the other hand, whitish or greenish color compact calli were produced in the presence of BAP and Kn supplemented media (Fig. 1b, Table 1). Chand and Sahrawat (2002) observed embryogenic nodular callus induction from root segments of Psoralea corylifolia L. on MS medium supplemented with BA and NAA. The root segment explants of $R$. serpentina showed interesting results on morphological variations. Direct plantlets formation was observed on MS with $4.0 \mathrm{mg} / \mathrm{l} \mathrm{BAP}+4.0 \mathrm{mg} / \mathrm{l} \mathrm{NAA}$ (Fig. $1 \mathrm{c}, \mathrm{d}$ ) where $45.4 \%$ callus showed complete plant-

Table 1. Effect of different concentrations and combinations of growth regulator on induction of morphogenic callus from in vitro root explants of $R$. serpentina.

\begin{tabular}{|c|c|c|c|c|}
\hline $\begin{array}{l}\text { Media } \\
\text { combination }\end{array}$ & $\begin{array}{l}\text { Intensity } \\
\text { of callus } \\
\text { formation }\end{array}$ & $\begin{array}{l}\text { Nature of } \\
\text { callus }\end{array}$ & $\begin{array}{c}\% \text { of } \\
\text { callus } \\
\text { formation }\end{array}$ & $\begin{array}{c}\% \text { of plantlets } \\
\text { regenerated } \\
\text { from callus }\end{array}$ \\
\hline $\mathrm{MS}+2.0 \mathrm{mg} / \mathrm{l} \mathrm{BAP}+0.5 \mathrm{mg} / \mathrm{l} \mathrm{NAA}$ & + & $\begin{array}{l}\text { Brown, unorganized } \\
\text { callus }\end{array}$ & - & - \\
\hline $\mathrm{MS}+2.0 \mathrm{mg} / \mathrm{l} \mathrm{BAP}+1.0 \mathrm{NAA}$ & + & $\begin{array}{l}\text { Brown, unorganized } \\
\text { callus }\end{array}$ & 12.5 & - \\
\hline $\mathrm{MS}+2.0 \mathrm{mg} / \mathrm{l} \mathrm{BAP}+2.0 \mathrm{mg} / \mathrm{l} \mathrm{NAA}$ & +++ & Cream, friable callus & 46.8 & 26.6 \\
\hline $\mathrm{MS}+4 \mathrm{mg} / \mathrm{BAP}+2 \mathrm{mg} / \mathrm{NAA}$ & +++ & Cream, friable callus & 46.8 & 32.3 \\
\hline $\mathrm{MS}+4 \mathrm{mg} / \mathrm{l} \mathrm{BAP}+4 \mathrm{mg} / \mathrm{l} \mathrm{NAA}$ & +++ & Cream, friable callus & 75 & 63.63 \\
\hline $\mathrm{MS}+1 \mathrm{mg} / \mathrm{l} \mathrm{BAP}+0.5 \mathrm{mg} / \mathrm{l} \mathrm{Kn}$ & ++ & $\begin{array}{l}\text { Greenish cream } \\
\text { compact callus }\end{array}$ & 31.75 & 40 \\
\hline $\mathrm{MS}+2 \mathrm{mg} / \mathrm{l} \mathrm{BAP}+1.0 \mathrm{mg} / \mathrm{Kn}$ & + & $\begin{array}{l}\text { Slow growing, whitish } \\
\text { compact callus }\end{array}$ & 26.6 & - \\
\hline $\mathrm{MS}+2 \mathrm{mg} / \mathrm{l} \mathrm{BAP}+2.0 \mathrm{mg} / \mathrm{l} \mathrm{Kn}$ & + & $\begin{array}{l}\text { Slow growing, whitish } \\
\text { compact callus }\end{array}$ & 16.6 & - \\
\hline
\end{tabular}

$+=$ Slight callus formation, $++=$ Good callus formation, $+++=$ Profuse callus formation.

Table 2. Morphogenic responses observed on MS medium with various hormonal combinations.

\begin{tabular}{lcccc}
\hline \multirow{2}{*}{$\begin{array}{l}\text { Media } \\
\text { combination }\end{array}$} & \multicolumn{4}{c}{$\begin{array}{c}\text { Morphogenic responses (\%) } \\
\text { callus of } R \text {. serpentina }\end{array}$} \\
\cline { 2 - 5 } & $\begin{array}{c}\text { Whole } \\
\text { plantlets }\end{array}$ & $\begin{array}{c}\text { Only aerial } \\
\text { part }\end{array}$ & $\begin{array}{c}\text { Only } \\
\text { roots }\end{array}$ & $\begin{array}{c}\text { Basal } \\
\text { callus }\end{array}$ \\
\hline MS + 2.0 mg/l BAP+ 2.0 mg/l NAA & - & 12 & 46 & 36.6 \\
MS+ 4 mg/l BAP + 4 mg/l NAA & 45.4 & 36.3 & 72.7 & 72.7 \\
MS+ 1 mg/l BAP+ 0.5 mg/l Kn & 13.3 & 45.7 & 46.6 & 36.6 \\
MS+ 2 mg/l BAP+ 0.5 mg/l Kn & - & 33.3 & 45.6 & 70 \\
\hline
\end{tabular}

lets or whole plantlet developments (Fig. 1e). In this arrangement of BAP and NAA aerial medium directly parts of shoots $(36.6 \%)$ were found well formed (Fig. 1f). On MS with $2.0 \mathrm{mg} / \mathrm{l}$ BAP and $2.0 \mathrm{mg} / \mathrm{l} \mathrm{NAA}$ vigorus rhizogenesis was found to form from the explants and occasionally only shoots were produced from the rooted structure (Fig. 1g). Sometimes only swelling and profuse roots were produced in the combinations of BAP and NAA (Fig. 1h). In some 
instances cotyledonary-stage of somatic embryos was found to produce on MS with $4.0 \mathrm{mg} / \mathrm{l}$ $\mathrm{BAP}+4.0$
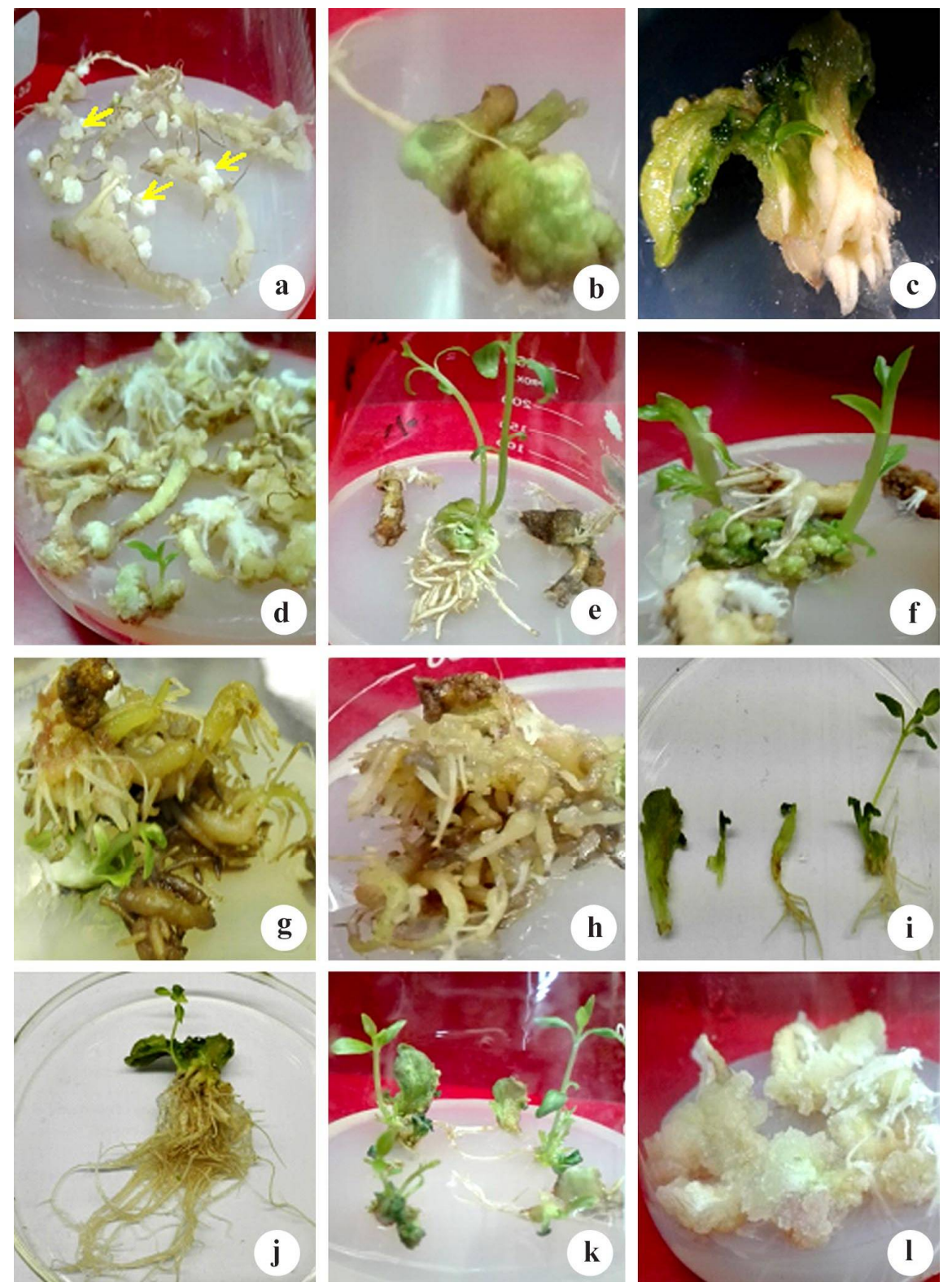

Fig. 1(a-1). Embryogenic callus induction and plant regeneration from root segments of $R$. serpentina L. (a) Nodular like embryogenic callus (arrow) were formed from root segments on MS medium with $4.0 \mathrm{mg} / \mathrm{l} \mathrm{BAP}$ and $4.0 \mathrm{mg} / \mathrm{l} \mathrm{NAA}$ after 4 week of culture; (b) Compact callus were formed on MS with BAP and Kn supplemented media; (c \& d) Regeneration of shoots and roots from embryogenic calli; (e) Fully developed plantlet (f \& g) showing the growth of only aerial part of shoots; h) Swelling and profuse roots; (i) Development of cotyledonary stages for the formation of a complete plantlets; (j) Cluster of plantlets with huge roots; (k) Formation of plantlets when the cluster of plantlets were sub-cultured separately; (1) Formation of only loosely arranged friable callus with roots. 
mg/l NAA supplemented from the root culture and finally produced mature plantlets (Fig. 1i). It was observed that huge number of roots were produced in a cluster of plantlets (Fig. 1j). When the cluster of plantlets was sub-cultured separately on fresh media, individual plantlets along with multiple shoots were produced (Fig. 1k). So often friable callus along with roots were observed on BAP and NAA supplemented medium (Fig. 11). Singh et al. (2009) reported the formation of callus and somatic embryo from leaf segment of $R$. serpentina on MS medium supplemented with BAP and IAA. According to Salma et al. (2008) high frequency of $96.43 \%$ callus was induced when nodal segments from in vitro raised shoots were cultured on MS medium supplemented with $0.5 \mathrm{mg} / \mathrm{l} \mathrm{BA}$ and $2.0 \mathrm{mg} / \mathrm{l} \mathrm{NAA}$.
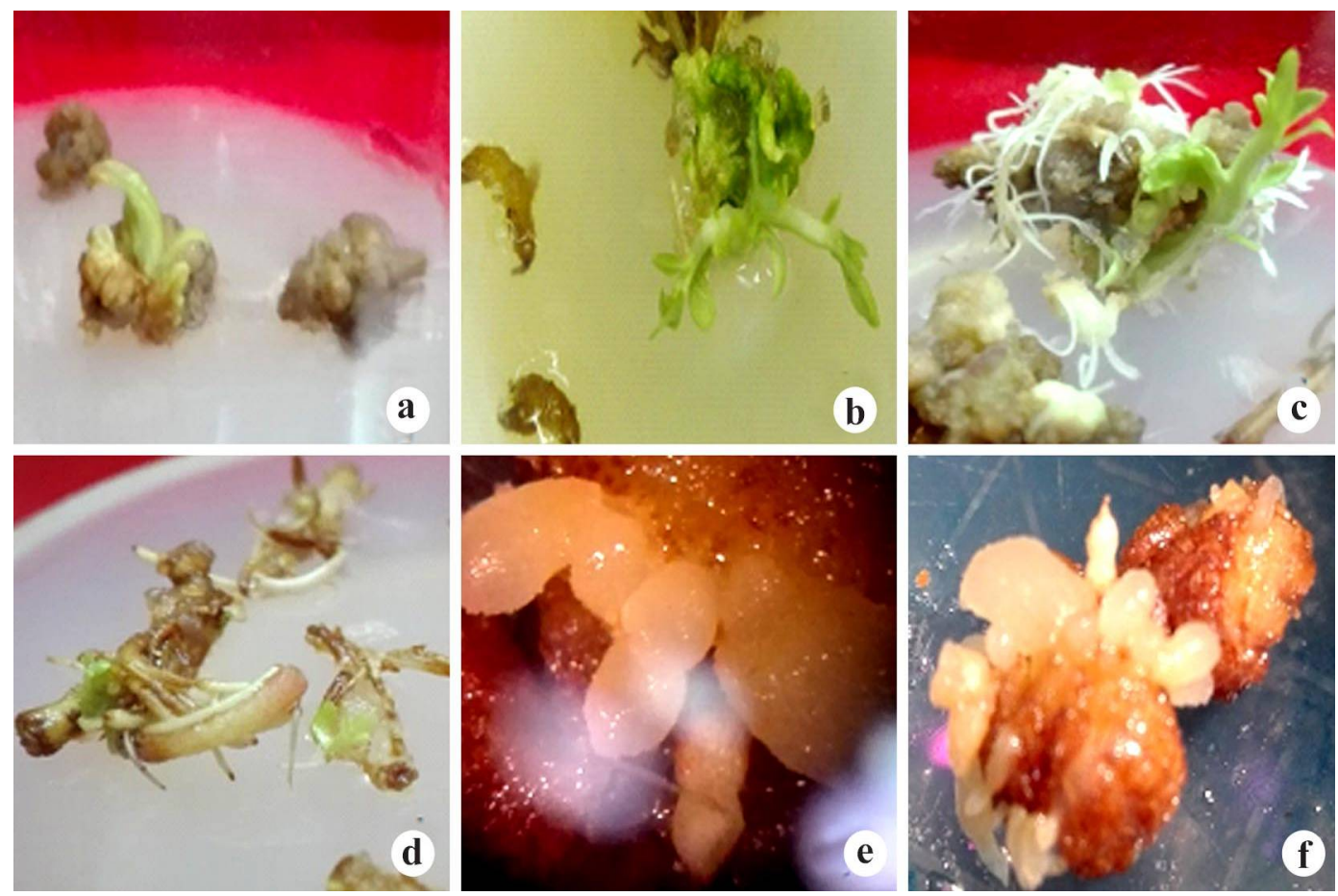

Fig. 2(a-f). Plant regeneration and somatic embryo formation from root segment used as explant. (a) Callus induction followed by shoot formation from the callus on MS with $1.0 \mathrm{mg} / \mathrm{l} \mathrm{BAP}+0.5 \mathrm{mg} / \mathrm{l} \mathrm{Kn}$ supplemented media; (b) Multiple shoot formation; (c) Whole plantlet formation from the callus; (d) Direct shoots were formed from the profuse roots; (e \& f) Well-developed globular somatic embryos were produced from the callus after 6-8 weeks of culture initiation.

On the other hand, MS with $1.0 \mathrm{mg} / \mathrm{l} \mathrm{BAP}+0.5 \mathrm{mg} / \mathrm{l} \mathrm{Kn}$ produced comparatively compact callus than BAP and NAA in addition to the media. Among the callus $45.7 \%$ callus showed only aerial part of shoots (Fig. 2a, b) whereas $13.3 \%$ callus was found to produce the whole plantlet formation (Fig. 2c). In some instant in BAP and Kn supplemented media the root explants swelled and only shoots were initiated directly from the profused roots (Fig. 2d). Subandil et al. (2018) applied NAA and Kn to promote and to regulate the growth of explant of $R$. serpentina cultured. Bhadra et al. (2013) reported that green and granular callus was produced on MS + $3.0 \mathrm{mg} / \mathrm{l} \mathrm{BAP}$ $+1.0 \mathrm{mg} / \mathrm{l} \mathrm{NAA}+1.5 \mathrm{mg} / \mathrm{l} \mathrm{Kn}$ from nodal explants of $R$. serpentina while loose and friable callus were produced on $0.1 \mathrm{mg} / \mathrm{l}$ picloram and $1.0 \mathrm{mg} / \mathrm{l} \mathrm{Kn}$ containing medium from the same explants. 
In this combination of $1.0 \mathrm{mg} / \mathrm{l} \mathrm{BAP}$ and $0.5 \mathrm{mg} / \mathrm{l} \mathrm{Kn}$ well-developed globular somatic embryos were found to form when the callus was placed more than $6-8$ weeks on the above-mentioned combination (Fig. 2e, f). It is widely accepted that somatic embryogenesis has many advantages over organogenesis such as good genetic stability and high propagation efficiency. Apart from that, somatic embryos of some plants can accumulate medicinal properties in gradients (Fulzele and Satdive 2003). But in the present experiment embryo like structures were failed to initiate plantlets when they were sub-cultured on PRG free MS medium. Germination of somatic embryos and regeneration into plants has been reported to be low for maximum species (Jayasankar et al. 2001) probably due to the structural abnormality of somatic embryos (Lee et al. 2002). In vitro propagation through somatic embryogenesis has been reported in many medicinal plants such as Eurycoma longifolia (Sobri et al. 2005), Ocimum basilicum L. (Gopi and Ponmurugan 2006) as well as in a few spruce and pine species (Haggman et al. 2005). The aerial part of shoots were cultured on half strengths of MS with $0.2 \mathrm{mg} / \mathrm{l} \mathrm{IBA}$ supplemented media for proper root formation. Similar to previous report (Khan et al. 2018), 80\% shoots produced roots. Well rooted plants were transplanted properly in soil with small pots.

Very few reports on plant regeneration using root segment of $R$. serpentina via embryogenic callus proliferation are available. In the present study, best plantlets regeneration was achieved from root segments derived embryogenic calluses of $R$. serpentina when explants were transferred to MS medium containing $4.0 \mathrm{mg} / \mathrm{l} \mathrm{BAP}$ and $4.0 \mathrm{mg} / \mathrm{l} \mathrm{NAA}$. The established regeneration system can be served as an alternative propagation method of $R$. serpentina to protect this endangered plant and to facilitate genetic modification. It can provide a ready supply of secondary metabolites, thereby alleviating pressure on existing resources already overexploited by uncontrolled harvesting.

\section{References}

Ahmed ZU, Begum ZNT, Hassan MA, Khondker M, Kabir SMH, Ahmed M, Ahmed ATA, Rahman AKA and Haque EU 2008. Encyclopedia of Flora and Fona of Bangladesh, Angiosperms Dicotyledons acanthaceae - Asteraceae. Vol. 6, Asiatic Society of Bangladesh.

Bhadra S, Bhowmik T and Singh P 2013. In vitro micropropagation of Rauvolfia serpentina (L.) Benth. through induction of direct and indirect organogenesis. Chittagong University Journal of Biological Sciences 3(1): 01-09.

Chand S and Sahrawat AK 2002. Somatic embryogenesis and plant regeneration from root segments of Psoralea corylifolia L., an endangered medicinally important plant. In Vitro Cell. Dev. Biol.-Plant 38: 33-38.

Fulzele DP and Satdive RK 2003. Somatic embryogenesis, plant regeneration, and the evaluation of camptothecin content in Nothapodytes foetida. In Vitro Cell. Dev.-Plant 39: 212-216.

Ghate VU, Gajendragadkar PM, Arun BJ 2019. Review of Rauvolfia serpentina (L.) Benth. Ex Kurz. International Journal of Research 8(6): 414-421.

Gomathi M 2015. Micropropagation of Rauwolfia Serpentina for enchancement of reserpine production and its transgenecity. Review of Literature. PhD Thesis, Vivekananda College of Arts and Science for Women.

Gopi C and Ponmurugan P 2006. Somatic embryogenesis and plant regeneration from leaf callus of Ocimum basilicum L. J. Biotechnol. 126: 260-264.

Goswami B, Hoque MI and Sarker RH 2018. Agrobacterium-mediated genetic transformation of oilseed Brassica juncea (L.) Journal of Natural Sciences Research 8 (Special Issue) for ICNST.

Haggman H, Vuosku J, Sarjala T, Jokela A and Niemi K (2005). Somatic embryogenesis of pine species from functional genomics to plantation forestry. In: Somatic Embryogenesis: Plant Cell Monographs. Second edition. A Mujib, Smaaj J. New York: Springer-Verlag Berlin. pp. 119-140. 
Itoh A, Kumashiro T and Yamaguchi M 2005. Indole alkaloids and other constituents of Rauvolfia serpentine. Journal of Natural Products 68(6): 848-852.

Jayasankar S, van Aman M, Li Z and Gray DJ (2001). Direct seeding of grapevine somatic embryos and regeneration of plants. In Vitro Cell Dev. Biol. 37: 476-479.

Khan S, Banu TA, Akter S, Goswami B, Islam M, Hani U and Habib A 2018. In vitro regeneration protocol of Rauvolfia serpentina L. Bangladesh J. Sci. Ind. Res. 53(2): 133-138.

Klushnichenko VE, Yakimov SY, Tuzova TP, Syagailo YV, Kuzovkina IN, Vulf'son AN and Miroshnikov AI 1995. Determination of indole alkaloids from $R$. serpentina and $R$. vomitoria by HPLC and TLC methods. J. Chromat. 704: 357-362.

Lee KS, Lee JC and Soh WY (2002). High frequency plant regeneration from Aralia cordata somatic embryos. Plant Cell Tissue Organ Cult. 68: 241-246.

Murashige T and Skoog F 1962. A revised medium for rapid growth and biossays with tobacco tissue cultures. Physiol. Plant 15: 473-497.

Pandey VP, Cherian E and Patani G 2010. Effect of growth regulators and culture conditions on direct root induction of Rauwolfia serpentina L. (Apocynaceae) Benth. by leaf explants. Tropical Journal of Pharmaceutical Research 9(1): 27-34.

Panwar GS and Guru SK 2011. Alkaloid profiling and estimation of reserpine in Rauwolfia serpentina plant by TLC, HP-TLC and HPLC. Asian Journal of Plant Sciences 10(8): 393-400.

Paturkar M and Khobragade P 2016. Mass cultivation of Sarpaganda in consideration with environmental factors and cultivation techniques. Int. J. Ayur. Pharma Research 4(10): 58-62.

Salma U, Rahman MSM, Islam S, Haque N, Jubair TA, Haque AKMF and Mukti IJ 2008. The influence of different hormone concentration and combination on callus induction and regeneration of Rauwolfia serpentina L. Benth. 11(12): 1638-1641.

Sharma RA and Gaikar VG 2012. Hydrotropic extraction of reserpine from Rauwolfia vomitoria Roots. Separation Science and Technology 47(6): 827-833.

Singh P, Singh A, Shukla Ak, Singh L, Pande V and Nailwal TK 2009. Somatic embryogenesis and in vitro regeneration of an endangered medicinal plant Sarpgandha (Rauvolfia serpentina L.). Life Science Journal 6(2): 57-62.

Sobri H, Rusli I, Anna LPK, Mohd Fadzillah N and Daud SK 2005. Micropropagation of Eurycoma longifolia via formation of somatic embryogenesis. Asian J. Plant Sci. 4: 472-485.

Subandil M, Dikayani and Firmansyah E 2018. Production of reserpine of Rauwolfia serpentina [L.] Kurz Ex Benth. through in vitro culture enriched with plant growth regulators of NAA and kinetin. International Journal of Engineering \& Technology, 7(2): 274-278.

Susila T, Reddy GS and Jyothsna D 2013. Standardization of protocol for in vitro propagation of an endangered medicinal plant Rauwolfia serpentina Benth, J. Med. Plants Res. 7(29): 2150-2153.

Verma KC and Verma SK 2010. Alkaloids analysis in root and leaf fractions of Sarpaghanda (Rauwolfia serpentina) Agric. Sci. Dig. 30(2): 133-135. 